The Insurgent Struggle Against the Soviet Occupiers in Vasyl Herasymiuk's Poetry

Author(s): Myroslav Laiuk

Source: Kyiv-Mohyla Humanities Journal 4 (2017): 113-121

Published by: National University of Kyiv-Mohyla Academy

http://kmhj.ukma.edu.ua/ 


\title{
The Insurgent Struggle Against the Soviet Occupiers in Vasyl Herasymiuk's Poetry
}

\author{
Myroslav Laiuk \\ National University of Kyiv-Mohyla Academy, \\ Department of Literature
}

\begin{abstract}
Vasyl Herasymiuk, one of the most prominent contemporary Ukrainian poets, presents the struggle of the insurgents against the Soviet occupiers in the Carpathians in his literary works as an opposition of "own" and "other." The invasion of the occupier destroys the authentic Carpathian cultural continuum and the insurgent underground resistance becomes a symbol of the human struggle for dignity and the preservation of own identity. The article analyzes the specific model of history presented in Vasyl Herasymiuk's poetry. The connection between the insurgency and the poet's biography and the history of his family is demonstrated. The article also traces and analyzes the contamination of the images of UPA insurgents and opryshky, the transformation in the hierarchical verticality of space, and the development of the struggle, presented via the opposition of "own" - "other," from a myth-ritual point of view.
\end{abstract}

Key Words: Vasyl Herasymiuk, poetry, insurgents, occupiers, the Carpathians.

\section{(7)}

\section{The Model of History}

The key historical events of Vasyl Herasymiuk's texts concern the middle of the 2oth century and the arrival in the Carpathians of the Soviet occupiers, who change the previous world order. They destroy the "best of the best" and deport them from their native land, demoralizing a population that has preserved its own archaic culture and formed an unchanging "Carpathian text." Herasymiuk's cultural, social, and axiological musings concern the collisions that emerge within the confines of these dimensions. Time is often reconfigured and contaminated, its ordering dependent on poetic imagery and ideology (for instance, the appearance in the same place and time of 18 th century opryshky ${ }^{1}$ and the poet's relative, a 2oth century insurgent, ${ }^{2}$ enables the

The opryshky were members of a peasant insurgency in Galicia, Transcarpathia, and Bukovyna against Polish nobles, Moldovan boyars, Hungarian feudals, and the Austrian administration from the 16 th century to the first half of the 19th century. The most celebrated leader and peasant protector was Oleksa Dovbush (1700-1745).

2 The Ukrainian Insurgent Army (the UPA) was a military and political formation, which operated in Ukraine during 1942-1953 and fought for Ukrainian independence against both Nazi Germany and the Soviet Union. 
opposition of "own" - "other" and the struggle between "good" and "evil," regardless of place and time).

The main stages of the poet's family history are connected with their struggle in the ranks of the insurgency and the family's survival or decimation (during deportation), and earlier, in the opryshky era, with its struggle against other occupiers.

Herasymiuk's book of selected poems Bula taka zemlia (There Was a Land, 2003) sums up his works of a thirty year period, its title emphasizing the existence of the poet's "land" in the past. Such a "land" no longer exists — it "was," not "is." The poet exposes the geographical parameters of the Carpathian land and its people with their history, rituals, and everyday life in a specific chronotope (before the conquest of the Soviet occupiers).

In his poetry Herasymiuk depicts changes in the landscape and demonstrates the history of the people. His generalizations may be transferred to centuries and millennia. For example, the poet reproduces the story of the forest, one of the main markers of Carpathian space: "When the wildwood died / and there was no young forest yet / the bare framework dawned terribly above the mountains" ("The Young Forest"). ${ }^{3}$ Modern (from the middle of the 2oth century) changes for the poet are so colossal that even the landscape changes noticeably. It speaks to witness the doomsday caused by people: "It rings loudly from the heights / booms from the chasms, / but at the very bottom / a closed mouth whispers: forgive me. / And the hills exhale: to no one" ("I've Already Heard This Laughter..."). The world is pre-apocalyptic for Herasymiuk (he is therefore considered a poet of eschatological outlook). ${ }^{4}$ Changes leading to an Apocalypse begin to occur when a "land" in its dimensional aspect and at its core is not able to exist in the "modern world." A pre-apocalyptic situation is accompanied by the destruction of linearity in the change of eras, and the emergence of a mythological time of chaos. "Have you already heard this laughter / on my hills. / In which dream? / In which millennium? / Whose grin? / Only laughter remains. / Laughter. / That is timeless. / As in myth" ("Have You Already Heard this Laughter...").

Therefore, linear historical time (in the poems "In Autumn at the End of the 1940s," "The Hurricane on Leading Sunday 1989" among others) is frequently moved to the past or to the future. Time transpires retrospectively and contaminates with other time and with eternity (as in the poem "1745 - Petrivka": opryshky "will sit till the end of the world." This chronotope enables the meeting of historical heroes of the 18th and 2oth centuries with biblical characters). For this temporality, the history of the poet's family becomes a micro-model for national and global history.

\section{Family History}

Herasymiuk's family history is one of the central concerns of his poetry. The chronological vertical of Herasymiuk's text is structured in accordance with his family history and his own biography, which are the bases for the construction his historical axis.

3 This and subsequent translations from the Ukrainian are mine.

4 Volodymyr Morenets, Oksymoron. Literaturoznavchi statti, doslidzhennia, esei [Oxymoron. Literary

Articles, Studies, Essays] (Kyiv: Ahrar Media Group, 2010), 419. 
Herasymiuk had eight years of schooling in his native village (Prokurava, Kosiv district, Ivano-Frankivsk region), spending his last two school years in Kolomyia. After graduation Herasymiuk studied at the Department of Ukrainian philology of Taras Shevchenko National University in Kyiv. Since that time the poet has lived in the capital and worked as an editor at the "Molod" and "Dnipro" publishing houses. From 1994 he has hosted literary programs at the state radio broadcasting company and in 2010 began hosting "Dialogue," his own program on the Culture Television Channel.

Viktor Neborak has said that "even the external canvas of Vasyl Herasymiuk's biography ... is full of appreciable tension." ${ }^{5}$ His grandfather on his father's side was a Sich Riflemen Army commander and died of his war wounds in $1932 .{ }^{6}$ One of his sons, Vasyl's uncle, was "captured with a weapon in his hands. For this he was sentenced to a twenty five year prison term. Both parents were deported." 7 Herasymiuk's mother's family is also unique. "Grandfather was among the commanders of the underground. His nom de guerre was Kotyhoroshko." 8 This means that the poet's grandfather and uncle were insurgents. "Kotyhoroshko" was imprisoned in the same cell with (in the future) Cardinal Joseph Slipyi. Herasymiuk's grandfather was sentenced to death, but "it was necessary that in such cases people should provide testimony about an atrocity. For example, that the guilty party drowned someone in a well or something like that. But he held such authority that no one was able to say anything," 9 so the verdict was changed to twenty five years of imprisonment. The poet sums up: "my father's and mother's families were in the UPA... all of them commanders." ${ }^{10}$

The way of life of Herasymiuk's ancestors and USSR state policies of the time predetermined the poet's birth in Karaganda (Kazakh Soviet Socialist Republic) on August 18, 1956. His parents, deported to Karaganda for "Ukrainian bourgeois nationalism," returned to Prokurava when Vasyl was still an infant (made possible after the 2oth Communist Party Congress in 1956, signaling change in Stalinist practices). In a commentary about his native village, Herasymiuk states "I have no lineage even from the neighboring village. They are all from Prokurava. There is a whole cemetery of them — three levels down." ${ }^{11}$ It is this place that becomes an extraordinary idealized locus: "We even live and die, despite that we are from Prokurava, / where the lord of this world puts his palm on your shoulder" ("To My Brother (Cousin)"). Thus the poet's relatives and society struggle as the opryshky (their ancestors) did before them - this resistance becoming a matter of honor.

5 Viktor Neborak, "Poet 'ostannikh rechei': Vasyl Herasymiuk i kinets mifolohii [The Poet of the 'Last Things': Vasyl Herasymiuk and the End of Mythology]," Litakcent, accessed March 12, 2017, http://litakcent.com/2011/o9/o2/poet-ostannih-rechej-vasyl-herasymjuk-i-kinec-mifolohiji/.

6 The Sich Riflemen (1917-1919) was one of the first regular military units of the Ukrainian People's Republic Army, formed from Ukrainian soldiers of the Austro-Hungarian army.

7 Taras Prokhasko, ed., Inshyi format: Vasyl Herasymiuk [Another Format: Vasyl Herasymiuk] (IvanoFrankivsk: Lileia NV, 2004), 13.

8 Prokhasko, Inshyiformat, 13 .

9 Prokhasko, Inshyiformat, 13.

10 Prokhasko, Inshyiformat, 12.

11 Prokhasko, Inshyiformat, 14. 


\section{Insurgents and Opryshky}

Herasymiuk proposes the opryshky as a typological equivalent of the insurgents. The opryshky struggled against other invaders in the Carpathians. They are mentioned in many poems, their images frequently contaminated. In the "Kyivan" poem "A Dream in the Subway" we meet Sviatoslav, an UPA insurgent (mentioned alongside of Kyivan Prince Sviatoslav Ihorovych). The poet's grandfather Vasyl (Yakibchuk) fought shoulder-to-shoulder with Sviatoslav. Time shifts in the poem "1745 - Petrivka" where the same grandfather Vasyl appears. The poem tells of how Dovbush calls his comrades-in-arms to the tavern of Yasinia village. Heroes and events of the 2oth century suddenly appear in a mid-18th century atmosphere: "My grandfather Vasyl dropped his carbine." The poem "Great-Grandfather" extends the historical axis of family to the poet's great-grandfather and beyond. This axis parallels the history of the poet's native village and the Carpathian region: Austrian parliamentary elections, the opryshky, salt producing, etc. History arises as a disordered phenomenon. Nevertheless, it is consolidated not in official statements but in family memory. "Great-grandfather is known, but who / will speak about his father? ... When everything is being lost? In the year of his birth? / In which churches, by which magistrates, / in which notanda - German, Polish / is that year noted?"

Insurgents often appear in Herasymiuk's poems. Their stories are told through kakhli authentic tiles used by Hutsuls (in the Carpathians). The "Kakhli (Tiles)" cycle is built on the ecphrasis principle: the poet reproduces the stories of artisan Bakhmatiuk's cycle of tiles. Oleksa Bakhmatiuk (1820-1882, Pistyn, Kosiv district, Ivano-Frankivsk region) was the founder of the Kosiv ceramic style. Some of his tiles depict simultaneous events - dynamic and strained stories. The poem "She Ran out from the House at Midnight..." focuses on different motives within a single plot. It is about a frightened woman, her hiding in a cherry-tree, and her taking food to a forest (obviously to an insurgent). Ultimately, the poetic vision focuses on a flow of water running from a bunker. Through the "kakhli stories" and other poems Herasymiuk illustrates the everyday life of the insurgents, their feats and problems. The poem "Running on Hilltops" contains an episode in which "the mother of the dead Sviatoslav / fell down on her mined son / and they both rose to heaven." A great number of Herasymiuk's texts are dedicated to stories of insurgents.

The poem "They Came at Night. Your Son is Dead..." is about a man who, having discovered his son's death, "tossed and turned over on a stove / as in a grave." But in the next line Herasymiuk writes: "No, not in a grave but in air..., because the man loses a sense of his presence in his former chronotope after the death of his descendant, and therefore of his family's continuation. The poem ends with the words: "They took him from the stream / carrying him to the forest... / And he, who has woken up, will cry. / Or maybe not. Because there will be no tears / Where are you turning over, Kosmach." These tragedies of ordinary people are superimposed onto the tragedy of the entire "land" via the "Kosmach" synecdoche; this "island" also turning over like a man in pain. Kosmach is also in the air now — which is why the old man, along with his land, rises into the air.

Consequently, there are two "lands" in Herasymiuk's works: a "heavenly land" and an "earthly land." "Earthly land" detests humans. In the poem "Autumn, the End of the 1940s" something absolutely alien to the world order takes place: "I can't embrace you / it's scary, scary everywhere / standing on such land / kissing you;" "it's good only in a stable" because only cattle still have "something tender, human, maternal." This scene takes place in a rustic landscape, and when 
an "other" nears, the female heroine - the beloved of the lyrical hero — "is removed from the land along with her milk." The erotic scene ends with a horrible episode: the hero (obviously the insurgent) is taken away from his beloved (after kissing her in the loft of the stable "with beech and sycamore leaves above them"). He is led with his hands tied, thrown into manure, and stepped on and beaten "until a beech or perhaps sycamore leaf flies in front of their somnolent eyes." In the poem "Stylization: Sonnet (I)": "the land where your breath is taken away / spins over heads." New changes brought by the occupiers overturn the hierarchical vertical in the imaginative consciousness.

\section{The Hierarchical Vertical}

The Hierarchical vertical is a significant feature for mythological consciousness as are the links between the center and periphery. Mircea Eliade states that the space gap (the beginning of the ritual act) represents the beginning of world creation because it provides the "starting point," the central axis for all future acts and movement. Space makes hierarchy relative to this center: "the manifestation of the sacred is ontologically the birth of the Universe."12 Mount Gregit is the heart of Herasymiuk's mythological world. A barrack is an opposition to Gregit in a traditional opposition of "top" / "bottom." At first thought, it can be seen as a symbolic "AntiGregit," a "bottom" with its traditional set of associations. But in Herasymiuk's poems this locus is inverted. The barrack (the word being associated primarily with a camp dwelling) becomes a location for acts of courage and humanity. It is where deported Carpathians, among them many of Herasymiuk's relatives and neighbors, have to live and die in inhuman conditions. A Carpathian insurgent kryivka (underground quarters) becomes an absolute equivalent to the Karaganda barracks. The poem "The Old Testament" contaminates two spaces: prison bunks in Kosiv (in the jail of The NKVD - The People's Commissariat for Internal Affairs) and the Karaganda barrack (the place where "bourgeois nationalists" were deported to). Kost Moskalets writes that "the geography and isolation of mountain regions and the self-sufficient Hutsul mentality transformed the insurgent movement into a metaphysical resistance of the human against the inhuman." "13 "The Old Testament" is a memoir about the old Carpathian world not yet acquainted with the linearity of time. Herasymiuk's "father in a typhoid barrack / was reading 'The Old Testament' / next to a corpse..." This hellish landscape is a meeting place for humans and the spiritual world: where Chuhaister (a character from Carpathian demonology) visits man. The reality of Karaganda moves "into the skies" — to the polonyna (a Carpathian mountain meadow), the poet's native space. Herasymiuk comments: "The meeting of man with the spiritual world is always dangerous and may end badly, regardless of the spirits he meets, good or evil."14 Setting up a polonyna bonfire should ensure a ritual transition to the transcendental. That is why a shepherd

12 Mircea Eliade, Sviashchenne i myrske. Mify, snovydinnia i misterii. Mefistofel i androhin. Okultyzm, vorozhbytstvo ta kulturni upodobannia [The Sacred and the Profane. Myths, Dreams and Mysteries. Mephistopheles and the Androgynous. Occultism, Witchcraft and Cultural Preferences] (Kyiv: Osnovy, 2001), 12. Kost Moskalets, "Paporot: etyka i poetyka," in Paporot by Vasyl Herasymiuk (Kyiv: Prosvita, 2006), 308. 
appointed to upkeep the bonfire was cruelly punished if the bonfire died out: "a bonfire dies out only once / which is why we keep it going." 2oth century events separated humans from the ability to communicate with the spiritual world. In the poem "The Old Testament" this meeting is so dramatic that any and all change in traditional hierarchical symbolic schemes is possible. The image of the "Book" in this poem serves as a symbol of transforming the "bottom" locus into a saving "top": "My father in a typhoid barrack / was reading 'The Old Testament.' And a corpse / lay nearby. As of yesterday. Like a cleared forest / the barrack yawned / Still there in the morning, / and father put the Book between him and it. He shut his eyes and opened them. / And could not break the silence. His sight got better. / The barrack rose up like polonyna smoke..." Herasymiuk proves that even in such conditions a person tries to preserve a connection with transcendental categories, reading "The Old Testament," which represents, the poet states, "not only a part of the Bible but also the world of Hutsul mythology, the connection between mountain people and spirits, and the transfer of this connection from generation to generation." ${ }^{15}$

For Herasymiuk a kryivka, an underground hiding place for insurgents, is a typological equivalent of a barrack. The poem "The Braid" unfolds a tragic story of everyday insurgent life: a woman insurgent has to live underground for a long time and asks a fellow insurgent to cut off her splendid long braid. But the man refuses to do so and looks after her hair for a long time. The braid becomes symbolic of world salvation and the act of combing it becomes a ritual act that provides the world with order and altogether with the possibility for existence.

As can be seen, the traditional "top" and "bottom" in Herasymiuk's spatial system are frequently subject to inversion. Mount Gregit remains as the highest stage of the poet's ethical coordinates, although the "bottom" barrack and kryivka are places of the struggle and death of "the best among the best," changing the axiological dimensions of these places. Alongside of this, the ritual-mythological opposition of "own" — "other" is intensified.

\section{"Own" and "Other"}

Each ritual act provides defining measures and establishes the connection between "own" and "other." Thus, participants of ritual are our "own," belonging to a particular community. The "other" is the world of spirits and demons, to which humans appeal to fulfill their needs. The "other" is hostile to human and community. Herasymiuk modifies this scheme in a certain way. A new form of "other" arises, against which Carpathian demons strategically unite with the people who live there.

Herasymiuk's "other" is someone who wants to damage or stereotype the Carpathian world, an occupier who causes chaos. In the profane world of the 2oth century the effect of ritual remains stably efficient for Herasymiuk because it functions with the same intensity it always did. However, there are now much fewer participants in the ritual act, the sphere of "own" has narrowed. Herasymiuk intensifies the ritualization of his texts, the aim of which is to save the world. Liudmyla Kiseliova makes an analogy to the definition of "religious non-musicality" (ritual indifference), supposing that Herasymiuk's texts are "religiously musical": 
that special ear for music that allows the poet to hear eternity despite the noise of the modern world, catch the harmony of the past and the future, maintain the infringed base of world order, and therefore implement "the ritual of word and world revitalization for their preservation." ${ }^{16}$

The definition of "other" in Vasyl Herasymiuk's poems varies. If in the Dovbush era it is a foreigner-invader, by the middle of the zoth century the occupier has changed (the NKVD). Today it is the businessman, an obyvatel (term for a disinterested narrow-minded person), and a tourist who perceives only the ethnographical Carpathians, devastating the authenticity of this land.

Herasymiuk does not make any effort to communicate with the world of the "other," whose reality is already marked with contexts of downfall, inhumanity, and indecency. Volodymyr Morenets states that Herasymiuk "observes objective reality from the side, from the carefully protective family mainland, which maintains a special pure space for itself even in a defunct existence, this "warm myth" being "the ground and horizon for all of Herasymiuk's images, the beginning and the end for his life's journeys." ${ }^{17}$

The mythologization of the historical struggle against occupiers of all times occurs on the basis of ritual differentiation between "own" and "other."

To become part of the "own" a person must be a party to collective ritual: "You must dance the arkan. / At least once," - the poet writes in “The Men's Dance." Participation in the arkan ritual men's dance, danced before battle, makes a man one's "own" and is needed to distinguish him from the "other," providing a family connection (blood ties), and thus obligations, and affiliation with a supra-personal community that provides access to the transcendental, unachievable for the "other": "At least once / Stand in this closest of circles / holding the shoulders of two brothers / holding their hands with deathly strength / and then in a sacred circle / you will dance under the endless expanse of the sky / in lengthy howls. / To keep yourself in this sinful world / at least once / with your neighbor / mix your blood and sweat /." One who broke the circle during the dance could not participate in other acts of the collective. The unity of the circle meant the responsibility of each person for everyone else, because community survival depended on this. "Holding hands with deathly strength" for Herasymiuk means standing with your brother till death, because the dance is a model of the life cycle.

One's "own"- insurgents and opryshky — stand up to "others" not only in ritual but also in battle. The events of the poem "1745 - Petrivka" first take place at an opryshky meeting in the tavern of Yasinia village, and then changes location to the square of the city of Ivano-Frankivsk, where Polish poet Franciszek Karpinski watches the execution of Baiurak, Dovbush's comradein-arms. Herasymiuk mentions a historical fact: the opryshky leader saved this "other" — a future poet - when he was an infant. Karpinski himself recalls his father abandoning his homestead before Dovbush's attack, leaving behind his pregnant wife. Upon their arrival the opryshky do not

16 Liudmyla Kiselova, Poetyka ta ideolohiia mifu Vasylia Herasymiuka [The Poetics and Ideology of Myth in Vasyl Herasymiuk] (Kyiv: NaUKMA, 2016), 6. 
kill the woman, and in return Dovbush asks to name the yet to be born infant "Oleksa." 18 When Herasymiuk shows Baiurak's execution he emphasizes: "The opryshok saved the poet. The poet did not save the opryshok."

One more episode has symbolic meaning, comrade-in-arms Fedio stays in the loft of the tavern, obviously watching over Dovbush and his brothers. The "other" does not find this "historical figure" (as Herasymiuk states); the opryshok will descend from the loft in 200 years in the 40 of of the 2oth century - reborn as an insurgent, a successive defender of the "land."

A new "other" - the occupier - attempts to disrupt the circle of mythological time, in which the land exists. He kills "the best of the best," deports entire families, and establishes new rules. Ever since "the best" had been killed, the "other" has authority over Carpathian space, main loci becoming tourist brands and sacral places becoming stops on tourist routes where the remnants of "authenticity" are hunted for.

The main historical events that Vasyl Herasymiuk focuses on occur in the middle of the 2oth century, when the Soviet occupiers arrive in the Carpathians, disrupting the ancient order. The local population joins the insurgency and struggle against those who have brought chaos to their land. This is a "historical rhyme" to the opryshky struggle, transforming the hierarchical vertical for the Carpathians: "bottom" becomes "top," because their hiding places — bunkers and shelters - become locations for sacred acts. The Carpathian community of one's "own" (including the poet's family) struggle against the "others," the Soviet occupiers, in order to save the authentic Carpathian world and their own dignity.

\section{Bibliography}

Eliade, Mircea. Sviashchenne imyrske. Mify, snovydinnia imisterii. Mefistofel i androhin. Okultyzm, vorozhbytstvo ta kulturni upodobannia [The Sacred and the Profane. Myths, Dreams and Mysteries. Mephistopheles and the Androgynous. Occultism, Witchcraft and Cultural Preferences]. Kyiv: Osnovy. 2001.

Karpiński, Franciszek. Historia mego wieku i ludzi, z którymi żyłem. Warsaw: Państ. Instytut Wydawniczy, 1987.

Kiselova, Liudmyla. Poetyka ta ideolohiia mifu Vasylia Herasymiuka [The Poetics and Ideology of Myth in Vasyl Herasymiuk]. Kyiv: NaUKMA. 2016.

Morenets, Volodymyr. Oksymoron. Literaturoznavchi statti, doslidzhennia, esei [Oxymoron. Literary Articles, Studies, Essays]. Kyiv: Ahrar Media Grup. 2010.

Moskalets, Kost. "Paporot: etyka i poetyka [The Fern: Ethics and Poetics]." In Paporot by Vasyl Herasymiuk. Kyiv: Prosvita, 2006.

Neborak, Viktor. "Poet 'ostannikh rechei': Vasyl Herasymiuk i kinets mifolohii [The Poet of the 'Last Things': Vasyl Herasymiuk and the End of Mythology]." Litakcent. Accessed March 12, 2017. http://litakcent.com/2011/o9/o2/poet-ostannih-rechej-vasyl-herasymjuk-i-kinecmifolohiji/.

18 Franciszek Karpiński, Historia mego wieku i ludzi, z którymi żytem (Warsaw: Państ. Instytut Wydawniczy, 1987). 
Prokhasko, Taras, ed. Inshyiformat: Vasyl Herasymiuk [Another Format: Vasyl Herasymiuk]. IvanoFrankivsk: Lileia NV, 2004.

\section{(7)}

Myroslav Laiuk is a PhD student at the Department of Literature of the National University of Kyiv-Mohyla Academy. He received his Master of Arts Degree in Literature in 2014. His research interests include the problem of the "Carpathian text" in Vasyl Herasymiuk's works. Myroslav Laiuk is also a published poet (2 collections) and the author of a debut novel Babornia (2016). 